\title{
REITERASI DALAM PRIANGAN SI JELITA DAN IMPLIKASINYA PADA PEMBELAJARAN BAHASA INDONESIA DI SMP
}

\author{
Asep Muhyidin \\ muhyidin21@untirta.ac.id \\ Universitas Sultan Ageng Tirtayasa Banten
}

\begin{abstract}
This research studied the use of reiteration in che ollection of poems Priangan Si Jelita. The object of this research is reiteration which consist of repetition, synonymy, metonymy, and hyponymy. This research used both theoretical and methodological approaches. The former was discourse analysis whereas the latter was qualitative-descriptive approach. The result of analysis shows that the strength and beauty of the forms and meanings of the poems in Priangan Si Jelita are mostly built by the lexical cohesive elements within, particularly reiteration covering repetition, synonymy, metonymy, and hyponymy. The most dominant reiteration in the poems is repetition. This research has an implication toward Indonesian language learning for class IX students of junior high school in the material of paraphrasing poems in accordance with the structure and principles of texts in written form.
\end{abstract}

Keywords: lexical cohesion, reiteration, poems, learning

\section{PENDAhuluan}

De Beaugrande (1981, 3-12) mengajukan adanya tujuh standar kewacanaan. Ketujuh standar kewacaan tersebut dapat menentukan apakah sesuatu itu dapat dikategorikan sebagai wacana atau bukan. Adapun standar kewacanaan tersebut adalah kohesi, koherensi, intensionalitas, akseptabilitas, informabilitas, situasionalitas, dan intertekstualitas. Puisi dapat dikategorikan salah satu bentuk wacana sastra karena memenuhi tujuh kriteria tersebut. Puisi terbentuk dari rangkaian kata-kata yang mengandung amanat atau pesan yang akan disampaikan penyair sebagai addressor dan akan dibaca oleh addressee.

Puisi merupakan bagian dari bentuk wacana. Kata sebagai esensi utama dari sebuah puisi telah berhasil keluar dari penjara kebuntuan leksikon, namun masih saja banyak di antara kita seakan melupakan bahwa puisi bukanlah sekedar kata. Otoritas kata di dalam puisi harus dikembalikan pada fleksibilitasnya, yaitu pada kemampuannya untuk menyatakan dirinya sendiri dalam bentuk apapun yang ia inginkan. Tidak saja secara verbal dimana kata dapat bertransformasi atau bermetamorfosis sesuai dengan yang ia kehendaki melainkan juga di dalam wujud visualnya yaitu di dalam tipografinya. Hal ini karena tipografi sebagai wadah atau bentuk dari sebuah puisi berfungsi untuk menyampaikan apa yang tersurat dari yang tersirat, ia dapat berfungsi sebagai salah satu pintu menuju pada pengertian dan interpretasi dari makna puisi tersebut. Puisi harus dapat mengkomunikasikan dirinya sendiri dan hadir sepenuhnya dengan identitasnya sendiri yang mewakili seluruh keberadaan dirinya secara utuh dan konkret.

Puisi memiliki ciri-ciri kebahasaan tersendiri. Bahasa pada puisi disajikan secara padat dan memiliki makna luas dalam setiap lariknya. Pemilihan kata dalam puisi menunjukkan identitas pengarang. Dengan adanya pemilihan kata, maka seorang penyair akan lebih dikenal dengan kekhasan dalam meramu sebuah kata yang tercermin dari keterkaitan bait satu ke bait lainnya. Dalam pemilihan kata yang 
khas, penyair harus memperhatikan makna kias, lambang, dan persamaan bunyi atau rima. Sebagai salah satu bentuk wacana sastra, bahasa puisi memiliki keindahan baik dari segi pilihan kata maupun makna. Kebermaknaan puisi dapat digali dari rangkaian kata-kata yang membentuknya. Kepaduan bentuk puisi dapat ditinjau berdasarkan kohesi leksikal yang terdapat dalam pilihan kata-katanya.

Analisis wacana mempunyai akarakar intelektual bukan hanya pada ilmu linguistik, tetapi dalam ilmu-ilmu sosial, ilmu filsafat, dan sastra. Analisis wacana dalam teks puisi dapat ditinjau dari kohesi leksikal yang membentuknya. Hasil analisis kohesi leksikal dalam puisi diharapkan dapat mengungkap keindahan kata-kata yang membangun kepaduan makna serta bentuk puisi.

Kohesi leksikal adalah kohesi yang disebabkan karena adanya kata-kata yang secara leksikal memiliki pertalian atau dengan kata lain kata-kata yang memiliki hubungan arti, baik memiliki maupun tidak memiliki hubungan bentuk. Kohesi leksikal atau perpaduan leksikal adalah hubungan leksikal antara bagian-bagian wacana untuk mendapatkan keserasian struktur secara kohesif. Unsur kohesi leksikal terdiri dari reiterasi, kolokasi, dan ekuivalensi. Tujuan digunakannya aspek-aspek leksikal di dalam sebuah teks diantaranya ialah untuk mendapatkan efek intensitas makna bahasa, kejelasan informasi, dan keindahan bahasa.

Kumpulan puisi Priangan Si Jelita adalah salah satu karya fenomenal Ramadhan KH. Puisi ini merupakan sebuah karya yang unik karena bentuk dan maknanya. Priangan Si Jelita terdiri dari tiga bagian, yakni 'Tanah Kelahiran', 'Dendang Sayang', dan "Pembakaran". Masing-masing bagian ini terdiri dari tujuh puisi. Jadi, jumlah seluruhnya ada 21 puisi. Puisi-puisi dalam Priangan Si Jelita merupakan puisi yang bernada romantis dan elegi tentang keindahan Tanah Priangan, cinta tanah air, dan kemerdekaan. Kumpulan puisi Priangan Si Jelita memperoleh hadiah Sastra Nasional Badan Musyawarah Kebudayaan Nasional (BMKN) sebagai kumpulan sajak terbaik periode 1957-1958.

Aghdam \& Hadidi (2015) dalam penelitiannya mengenai kohesi dan koherensi dalam berita politik dan artikel akademik menemukan kohesi leksikal berupa sinonimi dan kolokasi. Temuan yang paling mendominasi adalah sinonimi. Penelitian yang dilakukan Herianah (2014) tentang kohesi gramatikal dan leksikal dalam puisi menghasilkan temuan repetisi pada aspek leksikal yang terbagi atas repetisi mesodiplosis, epistrafa, anadiplosis, anaphora, dan epizeuksis. Selain itu, masih ada sinonimi, antonimi dalam bentuk oposisi mutlak, hiponimi, dan kolokasi. Selanjutnya, Putra (2014) dalam penelitiannya tentang aspek gramatikal dan leksikal wacana novel, dari aspek leksikal memperoleh temuan berupa repetisi, sinonimi, antonimi, hiponimi, kolokasi, dan ekuivalensi. Penelitian lain tentang kohesi leksikal juga dilakukan oleh Malgwi (2016) dengan objek penelitian berupa teks tertulis bahasa Inggris sebagai bahasa kedua bagi para calon guru. Dari penelitian tersebut ditemukan adanya reiterasi berupa pengulangan, sinonimi, superordinasi, kata khusus, dan kata umum.

Kohesi memegang peranan yang sangat penting dalam pemahaman sebuah wacana. Kohesi leksikal yang terkandung dalam puisi juga sangat menarik untuk ditelaah karena puisi dibentuk dari rangkaian pilihan kata yang puitis. Fokus penelitian ini adalah kohesi leksikal dalam kumpulan puisi Priangan Si Jelita karya Ramadhan KH. Adapun subfokusnya adalah penggunaan reiterasi pada kumpulan puisi tersebut. Berdasarkan latar belakang, fokus dan subfokus penelitian, dapat dirumuskan 
permasalahan penelitian sebagai berikut: (1) Bagaimanakah penggunaan reiterasi (repetisi, sinonimi, metonimi, dan hiponimi) dalam kumpulan puisi Priangan Si Jelita karya Ramadhan KH?; (2) Bagaimana implikasinya bagi materi pembelajaran bahasa Indonesia, khususnya di SMP?

\section{Tinjauan Pustaka \\ Kohesi Leksikal}

Flowerdew \& Mahlberg (dalam Haris \& Yunus, 2014) menyatakan bahwa kohesi leksikal adalah hubungan makna di dalam teks melalui unsur leksikal yang satu dengan unsur leksikal yang lain yang menjadikan teks menjadi kohesif sehingga terjadi kesinambungan dalam teks tersebut. Dengan kata lain, kohesi leksikal adalah hubungan semantik antar unsur pembentuk wacana dengan memanfaatkan unsur leksikal atau kata.

Ada dua wujud kohesi leksikal, yaitu reiterasi dan kolokasi. Reiterasi secara umum terdiri dari repetisi, sinonimi, metonimi, dan hiponimi. Reiterasi adalah pengulangan katakata pada kalimat berikutnya untuk memberikan penekanan bahwa katakata tersebut merupakan fokus pembicaraan.

Halliday \& Hasan (dalam Malah 2015) membagi kohesi menjadi dua macam yaitu kohesi gramatikal dan kohesi leksikal. Kohesi leksikal sendiri terdiri atas reiterasi dan kolokasi. Reiterasi didalamnya termasuk repetisi, sinonimi, sinonim dekat, hiponimi, dan kata generik.

Rentel (dalam Rani dkk 2004, 129) menyatakan bahwa peranti kohesi leksikal terdiri atas dua macam. Pertama, reiterasi atau pengulangan, yakni piranti kohesi yang digunakan dengan mengulang suatu proposisi atau bagian dari proposisi. Reiterasi ini meliputi repetisi (ulangan) dan ulangan hiponim. Kedua, kolokasi, yaitu kata yang menunjukkan adanya hubungan kedekatan tempat (lokasi).
Repetisi merupakan salah satu cara untuk mempertahankan hubungan kohesif antarkalimat. Hubungan tersebut dibentuk dengan mengulang sebagian kalimat. Menurut Zaimar dan Harahap (2011, 148) repetisi adalah pengulangan kata yang sama, biasanya dengan acuan yang sama juga. Seluruh konstituen yang telah disebutkan diulang seluruhnya. Hal ini bukan hanya menunjukkan sifat kohesif dari teks, melainkan juga menyembunyikan makna konotatif tertentu tergantung dari konteksnya.

Tutescu (dalam Zaimar dan Harahap 2011, 149) mengemukakan bahwa sinonim adalah alat kohesi yang berupa hubungan dua leksem atau lebih. Unsur leksikal sinonim dapat saling menggantikan tanpa mengubah makna ujaran. Penggunaan sinonim sangat menopang kohesi sebuah wacana. Pengulangan yang bervariasi ini menjadikan teks semakin padu.

Kridalaksana $(2001,137)$ menjelaskan bahwa metonimi adalah pemakaian nama untuk benda lain yang berasosiasi atau menjadikan atributnya. Misalnya 'Si Kacamata' untuk seseorang yang selalu memakai kacamata. Metonimi dikenal juga sebagai sejenis majas atau gaya bahasa yang memakai ciri atau nama hal yang ditautkan dengan nama orang, barang atau hal lain sebagai penggantinya.

Hiponimi menurut Tutescu (Zaimar dan Harahap 2011, 151) merupakan suatu pencakupan makna. Hubungan pencakupan makna itu bersifat sepihak atau tidak simetris. Dua kata atau lebih tercakup dalam satu kata lain atau dapat dikatakan leksem yang lebih spesifik tercakup dalam leksem yang lebih umum. Hiponimi adalah hubungan pengulangan kata atau frasa dalam kalimat dengan kata atau frasa pada kalimat lain yang maknanya lebih spesifik.

Berdasarkan uraian teoretis di atas, reiterasi dalam penelitian ini mencakup repetisi, sinonimi, metonimi, dan hiponimi. 


\section{Pengertian Puisi}

Coloridge (dalam McRae 1998, 1) menyatakan bahwa puisi merupakan kata-kata terindah dalam susunan terindah (poetry is the best words in the best order). Pernyataan ini selaras dengan pendapat yang menyatakan bahwa dalam puisi ada unsur keindahan. Kata-kata yang dipilih berada dalam komposisi yang indah dan bernilai seni (arts). Dengan demikian, bahasa dalam puisi terdiri dari rangkaian kata-kata terpilih yang dapat menyampaikan perasaan, pemikiran, dan nilai keindahan di dalamnya.

Bahasa puisi secara konvensional bersifat ekspresif, sugestif, asosiatif, dan magis. Ekspresif memiliki makna bahwa setiap bunyi yang dipilih, setiap kata yang dipilih, dan setiap metafora yang digunakan harus berfungsi bagi kepentingan ekspresi, mampu memperjelas gambaran, mampu menimbulkan kesan yang kuat, dan dapat mewakili perasaan penyairnya. Kemudian, sugestif memiliki makna bahwa bahasa dalam puisi bersifat menyarankan dan mempengaruhi pembacanya sehingga puisi dapat berkesan sangat kuat dalam diri penikmatnya. Sementara asosiatif memiliki makna bahwa bahasa dalam puisi mampu membangkitkan pikiran dan perasaan.

Bahasa dalam puisi dapat memiliki kegandaan tafsir karena bahasa puisi penuh simbol dan lambang personal. Sesuai dengan pernyataan tersebut, Wordsworth (dalam Alwasilah 2006, 28) bahwa puisi merupakan letupan perasaan yang kuat secara tiba-tiba yang berasal dari perasaan bercampuraduk dalam keselarasan.

Puisi merupakan pemikiran manusia secara konkrit dan artistik dalam bahasa emosional dan berirama. Kiasan-kiasan dan unsur citraan dalam puisi disusun secara artistik (selaras, simetris, pilihan katanya tepat, bahasanya penuh perasaan serta berirama).
Bukan hanya pada bentuk fisik saja, apa yang diungkapkan dalam puisi juga merupakan rekaman detikdetik paling indah dalam hidup seperti peristiwa-peristiwa yang sangat mengesankan dan menimbulkan keharuan yang kuat. Perasaanperasaan tersebut seperti kebahagiaan yang memuncak, percintaan, bahkan kesedihan, dan kematian. Semua peristiwa dan perasaan dapat dituangkan dalam bentuk puisi dengan cara yang sangat artistik.

Berdasarkan uraian teoretis tentang hakikat puisi, dapat disimpulkan bahwa puisi merupakan sarana pengungkapan perasaan dan pemikiran tentang sesuatu dengan menggunakan bahasa yang indah sebagai media pengungkapannya.

\section{Metodologi Penelitian}

Penelitian ini menggunakan dua pendekatan, yaitu pendekatan teoretis dan pendekatan metodologis. Pendekatan teoretis dalam penelitian ini berupa analisis wacana. Menurut Cook (dalam Rani dkk 2004, 9) analisis wacana merupakan kajian mengensi wacana. Sementara, wacana itu sendiri adalah bahasa yang digunakan dalam komunikasi. Tujuan analisis wacana adalah untuk memerikan fungsiwacana dalam sebagai alat komunikasi. Wacana yang dijadikan objek penelitian ini berupa wacana puisi.

Pendekatan kedua dalam penelitian ini adalah pendekatan metodologis berupa pendekatan deskriptifkualitatif. Pendekatan deskriptif menurut Sudaryanto (1993, 63) adalah pendekatan yang lebih menekankan pada hasil penelitian yang bersangkutan dengan penggunaan bahasa tahap demi tahap dan langkah demi langkah. Adapun pendekatan kualitatif berkaitan dengan data yang tidak berupa angka-angka tetapi berbentuk satuan lingual.

Data penelitian ini adalah larik demi larik puisi-puisi yang terdapat dalam kumpulan puisi Priangan Si 
Jelita karya Ramadhan KH. Baris-baris puisi yang dijadikan data penelitian ini adalah baris yang di dalamnya diduga terdapat hubungan kohesi leksikal reiterasi.

Dengan sendirinya, sumber data yang digunakan dalam penelitian ini adalah puisi Priangan Si Jelita karya Ramadhan $\mathrm{KH}$ yang terdiri dari tiga bagian, yaitu 'Tanah Kelahiran', 'Dendang Sayang', dan 'Pembakaran'. Masing-masing bagian ini berisi tujuh puisi.

Kemudian, metode yang digunakan dalam pengumpulan data pada penelitian ini adalah metode simak. Dalam ilmu sosial, metode simak atau penyimakan dapat disejajarkan dengan metode pengamatan atau observasi karena kegiatan yang dilakukan pada dasarnya adalah menyimak atau mengamati penggunaan bahasa (Sudaryanto 1993, 133). Penggunaan bahasa yang dimaksud berupa penggunaan bentuk kohesi leksikal reiterasi pada seluruh baris puisi dalam Priangan Si Jelita. Penelitian ini difokuskan pada kohesi leksikal reiterasi yang terdapat pada sumber data, meliputi repetisi, sinonimi, metonimi, dan hiponimi.

Analisis data penelitian ini dilakukan dengan cara menata secara sistematis data yang berhubungan dengan subfokus penelitian. Adapun langkah-langkah yang dilakukan dalam analisis data adalah sebagai berikut:

1. Memilah korpus data dari naskah kumpulan puisi Priangan Si Jelita

2. Mereduksi, yaitu mengidentifikasi, kemudian menyeleksi, dan mengklasifikasikan korpus data

3. Menyajikan data, yaitu menata, mengkode, dan menganalisis data

4. Menarik simpulan sementara sesuai hasil reduksi dan penyajian data.

\section{Hasil dan Pembahasan Repetisi}

Berikut ini pemarkah kohesi leksikal reiterasi berupa repetisi yang ditemukan dalan kumpulan puisi
Priangan Si Jelita karya Ramadhan KH. Dalam kumpulan puisi ini ditemukan sebanyak 38 repetisi. Berikut ini contoh repetisi tersebut.

(1) Jamrut di pucuk-pucuk, Jamrut di air tipis menurun.

(Tanah Kelahiran, bagian I bait ke-2)

(2) Gadis dendang di ladang pisang, belum tahu manis jantungnya.

Aduhai!

Gadis dendang di matahari, hanya bisa tahu teriknya.

Aduhai!

(Dendang Sayang, V/1)

(3) Tiada ranting kebahagiaan,

Burung malam tiada terbang.

Tiada daun kebebasan,

juga sedap malam ketakutan

(Pembakaran, VI /2)

Pada data (1) terdapat repetisi yaitu kata jamrut yang merupakan bentuk tidak baku dari kata 'zamrud' yang berarti 'batu permata hijau seperti lumut' (KBBI, 2008, 1569). Pemilihan kata jamrut ini menggambarkan suasana pagi hari di wilayah Priangan dimana embun bertebaran di pucukpucuk daun. Hal ini makin menguatkan citra keindahan alam wilayah Priangan.

Pada data (2) terdapat repetisi kata dan repetisi frasa yaitu kata 'aduhai' dan frasa 'gadis dendang'. Kata 'aduhai' merupakan kata seru untuk menyatakan kekaguman terhadap sesuatu (KBBI 2008, 12), sedangkan frasa 'gadis dendang' berarti anak perawan yang bernyanyi riang gembira sambil bekerja di ladang. Diksi 'aduhai' disandingkan dengan diksi 'gadis' dendang mencitrakan kesenangan dan suasana riang gembira yang dialami oleh seorang anak perawan saat bekerja di ladang.

Kemudian, pada data (3) terdapat repetisi kata 'tiada'. Pemilihan kata 'tiada' ini sangat berkontradiksi dengan pilihan kata pada data sebelumnya. Kata 'tiada' sendiri merupakan bentuk lain dari 'tidak ada'. Bait tersebut mengesankan ketiadaan kebebasan dan ketiadaan kebahagiaan, suasananya 
begitu sunyi dan mencekam. Hal ini sejalan dengan judul bagian puisi yaitu Pembakaran.

Repetisi adalah pengulangan satuan lingual yang dapat berupa bunyi, kata, frasa atau bagian kalimat yang dianggap penting untuk memberi tekanan dalam sebuah konteks puisi yang sesuai. Puisi adalah salah satu bentuk karya sastra yang terus berkembang sesuai selera dan konsep estetik yang berbeda-beda dari masa ke masa sampai saat ini.

Namun ada beberapa pendapat yang bisa menjelaskan hakikat puisi sebagai salah satu bentuk karya sastra. Puisi sebagai karya seni itu puitis. Puisi yang puitis dapat membangkitkan perasaan, menarik perhatian, menimbulkan tanggapan yang jelas, dan menimbulkan keharuan. Kepuitisan dalam puisi dapat dicapai dengan cara visual (tipografi dan susunan bait), bunyi (sajak, asonansi, aliterasi, kiasan bunyi, lambang rasa, dan orkestrasi), pilihan kata, bahasa kiasan, sarana retorika, unsur lingual, dan sebagainya.

\section{Sinonimi}

Dalam puisi-puisi Priangan $S i$ Jelita juga ditemukan sebanyak 4 pemarkah reiterasi sinonimi. Untuk lebih jelasnya dapat dilihat pada contoh berikut:

(4) Kembang tanjung berserakan

dipungut gadis berdendang

(Tanah Kelahiran, III/3)

Dan mawar merah

disobek di tujuh arah,

dikira orang menyanyi,

lewat di kayu kecap

(Tanah Kelahiran, V/2)

(5) Tengok dataran tanah priangan,

Gadisku manis

Dan si dara tiada bisa berkata

(Dendang Sayang, IV/3)

(6) Dara!

Kalau mau ganti warna

(Pembakaran, II/5)

Kalau gadis-gadis mesti jadi perawan

tua,

Sebab malam ketakutan
(Pembakaran, VI/3)

Pada data (4) terdapat sinonimi kata 'berdendang' dengan kata 'bernyanyi'. Kata 'berdendang' diartikan sebagai 'bernyanyi untuk bersenang-senang' (KBBI 2008, 311). Pateda (2010, 222) menjelaskan bahwa secara etimologi kata 'sinonimi' (Inggris: synonymy) berasal dari bahasa Yunani Kuno; onoma yang berarti nama dan syn yang berarti dengan. Sehingga makna harfiahnya adalah 'nama lain untuk benda yang sama'.

Sinonimi atau dikenal dengan sebutan padan kata adalah hubungan semantik yang menyatakan adanya kesamaan makna antara satu satuan ujaran dengan ujaran lainnya. Sinonimi berfungsi untuk menjalin hubungan makna yang sepadan antara satuan bahasa tertentu dengan satuan bahasa lain dalam wacana.

Pada data (5) dan (6) ditemukan kata 'gadis' dan 'dara'. Kata yang pertama dapat diartikan sebagai 'anak perempuan yang belum kawin' atau 'anak perawan'. Pemilihan kata 'dara' lebih mencitrakan keriangan dan kegembiraan. Dalam masyarakat Priangan istilah 'dara' ini juga biasa dilekatkan pada sejenis burung yaitu burung dara atau merpati. Burung merpati merupakan lambang kebebasan karena burung ini biasa terbang bebas kemana saja. Selain lambang kebebasan, merpati juga merupakan lambang perdamaian dan cinta.

Penggunaan sinonimi menjadikan puisi ini tidak monoton tetapi sangat bervariasi dari segi pilihan kata dan tipografinya. Sinonimi merupakan suatu jenis relasi makna yang terbentuk akibat adanya kesamaan makna diantara kata yang satu dengan kata yang lain. Kemudian, untuk mengetahui suatu kata merupakan sinonim dari kata lain atau bukan, kata tersebut dapat dimasukan ke dalam sebuah konteks kalimat. Apabila kata tersebut mampu menggantikan 
kata yang lain untuk membentuk sebuah konteks dengan makna kalimat yang sama, maka dapat dipastikan kedua kata tersebut bersinonim.

\section{Metonimi}

Pemarkah kohesi leksikal reiterasi metonimi yang ditemukan dalam Priangan Si Jelita ada sebanyak 16 kata. Berikut ini adalah contoh penggunaan metonimi.

(7) Berbelit membiru jalan

Ke Gede_dan Pangrango

Lewat musim penghujan

(Tanah Kelahiran, IV/1)

(8) Pacar gugur tiada menemu kuburannya

Dan si dara hanya bisa meraba,

Membelitkan kalung kenangannya

(Dendang Sayang, IV/2)

(9) Dara

Sudah lari bersembunyi

Sejak senja.

Kota ditikam menyendiri

(Pembakaran, VI/1)

Pada data (7) terdapat metonimi kata 'Gede' dan 'Pangrango'. Ungkapan metonimis 'Gede' mengacu kepada wilayah gunung Gede. Gunung tersebut terdapat di wilayah perbatasan kabupaten Cianjur, kabupaten Bogor, dan kabupaten Sukabumi. Sementara Kata 'Pangrango' mengacu kepada wilayah gunung Pangrango. Gunung Pangrango merupakan gunung kedua tertinggi di wilayah Priangan. Gunung ini bersebelahan dengan gunung Gede yang masuk dalam wilayah Taman Nasional Gede Pangrango.

Jalan antara Bogor dan Cianjur melintasi kaki kedua gunung tersebut di daerah Puncak yang kondisinya sangat indah. Kondisi jalan meliuk-liuk di antara perkebunan teh yang terhampar luas ribuan hektar.

Pada data (8) terdapat ungkapan metonimis 'si dara'. Kemudian pada data (9) terdapat metonimi kata 'dara'. Diksi 'si dara' dan 'dara' ini mengacu kepada anak perempuan yang belum menikah atau lebih dikenal dengan sebutan anak perawan. Dalam konteks puisi tersebut ungkapan 'si dara' dan 'dara' mengesankan suasana yang sunyi sepi bagaikan suasana di kuburan.

Metonimi merupakan suatu bentuk kreatif berbahasa yang berasal dari sisi fungsi bahasa. Kreativitas pemakaian bahasa tersebut termanifestasikan dengan diberdayakannya beragam benda di sekitar penutur yang diasumsikan dapat mewakili maksud penutur. Sifat hubungan antara makna acuan dengan makna teracu, cenderung pada makna keseluruhan yang mempengaruhi makna bagianbagiannya yang harus ditafsirkan di dalam satu domain.

\section{Hiponimi}

Hiponimi yaitu satuan kata yang maknanya dianggap sebagai bagian makna satuan kata yang lain. Hiponimi ini terjadi karena adanya persamaan makna di antara kata yang berhiponim. Dalam Priangan Si Jelita ditemukan sebanyak empat kasus hiponimi. Untuk lebih jelasnya dapat dilihat pada data berikut.

(10) Seruling di pasir ipis, merdu antara gundukan pohon pina, tembang menggemadi dua kaki, Burangrang -Tangkubanprahu.

(Tanah Kelahiran, I/1)

(11) Di Cikajang hanya burung, bebas lepas terbang lari. di bumi bayi turunnya, besar di bawah mengungsi; sepi di bumi Priangan, sepi menghadapi mati

(Dendang Sayang, I/3)

Pada data (10) penggunaan satuan lingual 'di dua kaki', BurangrangTangkubanprahu' merupakan bentukan yang berhiponimi. Satuan 'Burangrang -Tangkubanprahu' merupakan hiponim dari satuan 'di dua kaki' sebagai hipernim. Burangrang dan Tangkubanprahu mengacu kepada dua buah gunung yang berdampingan di daerah Bandung Utara yang lekat dengan legenda Sangkuriang. 
Data (11) menunjukkan kata 'Priangan' sebagai sesuatu yang umum, dan kata 'Cikajang' menunjukkan sesuatu yang lebih khusus. Cikajang merupakan bagian dari Priangan sehingga kedua kata tersebut dikatakan memiliki hubungan

Indonesia diarahkan untuk meningkatkan kemampuan siswa untuk berkomunikasi dalam Bahasa Indonesia dengan baik dan benar, baik secara lisan maupun tulis serta menumbuhkan apresiasi terhadap karya kesastraan manusia Indonesia.

Tabel: Perbandingan Reiterasi dalam Priangan Si Jelita

\begin{tabular}{|c|c|c|c|c|c|c|}
\hline \multirow{2}{*}{ Bagian Puisi } & \multicolumn{4}{|c|}{ Jenis Reiterasi } & \multirow{2}{*}{ Jumlah } & \multirow{2}{*}{ Persentase } \\
\hline & $\mathbf{R}$ & $\mathbf{S}$ & $\mathbf{M}$ & $\mathbf{H}$ & & \\
\hline Tanah Kelahiran & 16 & 1 & 9 & 2 & 28 & $45 \%$ \\
\hline Dendang Sayang & 12 & 1 & 4 & 1 & 18 & $29 \%$ \\
\hline Pembakaran & 10 & 2 & 3 & 1 & 16 & $26 \%$ \\
\hline Jumlah & 38 & 4 & 16 & 4 & 62 & $100 \%$ \\
\hline
\end{tabular}

Keterangan: R: Repetisi; S: Sinonimi; M: Metonimi; H; Hiponimi

hiponimi. Wilayah Cikajang terkenal sebagai daerah yang indah dan hawanya sangat sejuk karena berada di daerah dataran tinggi di wilayah kabupaten Garut.

Kemudian, pada data (12) satuan lingual 'hari ini', 'pagi' dan 'malam' merupakan satuan-satuan yang berhiponimi. Satuan 'hari ini' sebagai hipernim, lalu satuan 'pagi' dan 'malam' merupakan hiponim.

\section{Implikasi Reiterasi bagi Pembelajaran Bahasa Indonesia}

Kurikulum 2013 bertujuan untuk mempersiapkan insan manusia Indonesia agar memiliki kemampuan hidup sebagai pribadi dan warga negara yang beriman, produktif, kreatif, inovatif, dan afektif serta mampu berkontribusi pada kehidupan bermasyarakat, berbangsa, bernegara, serta peradaban dunia. Kurikulum 2013 dikembangkan berdasarkan budaya Indonesia yang beragam, baik beragam agama, suku, budaya maupun bahasa diarahkan untuk membangun kehidupan masa kini. Diharapkan pula untuk membangun dasar bagi kehidupan bangsa yang lebih baik di masa depan. Pembelajaran bahasa
Bahasa Indonesia dalam kurikulum 2013 tidak semata diajarkan sebagai ilmu pengetahuan tetapi dipraktikkan sebagai penghela ilmu pengetahuan. Hal ini dilakukan karena Kurikulum 2013 dirancang untuk menyongsong model pembelajaran abad 21 yang didalamnya terdapat pergeseran dari siswa diberi tahu menjadi siswa mencari tahu.

Oleh karena itu, peran bahasa menjadi sangat sentral. Pembelajaran bahasa Indonesia memiliki peranan yang sangat penting bukan hanya untuk membina keterampilan komunikasi melainkan juga untuk kepentingan penguasaan ilmu pengetahuan. Mengingat fungsi penting pembelajaran bahasa, sudah selayaknya pembelajaran bahasa di sekolah dilaksanakan dengan sebaikbaiknya.

Dalam pembelajaran Bahasa Indonesia, bentuk kegiatan pembelajaran harus berorientasi pada siswa. Dalam menentukan bentuk kegiatan pembelajaran, guru harus mempertimbangkan karakteristik siswa. Pada kegiatan belajar mengajar di dalam kelas, siswa harus berperan aktif dan bertanggung jawab dalam 
pembelajaran. Intinya, guru dan siswa harus bekerja sama dalam satu arah sehingga akan timbul pemahaman yang tepat meneganai aktivitas pembelajaran. Pengajaran bahasa yang semula difokuskan pada kegiatan guru mengajar (focus on the teacher), kini lebih banyak difokuskan pada kegiatan siswa belajar (focus on the learner).

Penelitian ini memiliki implikasi pada pembelajaran siswa SMP, khususnya kelas IX, terutama berkaitan dengan materi Bahasa Indonesia 'menyusun teks parafrase puisi sesuai dengan struktur dan kaidah teks secara tertulis'. Aspek pembelajaran ini akan menuntut siswa untuk memahami penanda leksikal yang berupa reiterasi yang meliputi repetisi (ulangan penuh, ulangan bentuk lain) sinonimi, metonimi, dan hiponimi yang berfungsi membuat suatu teks menjadi padu. Oleh karena itu, hasil penelitian ini sedikit banyak dapat diintegrasikan dengan materai pembelajaran bahasa Indonesia Kelas IX SMP.

Berdasarkan tujuan pembelajaran, guru harus mampu membuat skenario pembelajaran yang bisa membuat siswa mampu untuk menggunakan penanda leksikal berupa reiterasi dengan tepat sehingga siswa mampu menciptakan suatu paragraf yang kohesif. Langkahlangkah pembelajaran dapat dilakukan sebagai berikut:

1. Guru memberikan materi mengenai syarat-syarat paragraf yang padu berkaitan dengan penggunaan penanda leksikal jenis reiterasi

2. Tiap-tiap siswa ditugasi untuk membaca sebuah puisi kemudian mengidentifikasi penggunaan pemarkah kohesi leksikal jenis reiterasi yang terdapat pada puisi tersebut

3. Guru menugasi siswa untuk memparafrasekan puisi tersebut dengan menggunakan kalimat sendiri secara padu dengan menggunakan pemarkah kohesi leksikal reiterasi sebagai alat untuk mempertahankan kekohesifannya

4. Setelah tugas selesai, hasil tulisan ditukar dengan teman sebangku

5. Tiap-tiap siswa ditugasi untuk mengidentifikasi penggunaan pemarkah kohesi leksikal reiterasi yang ada pada tulisan temannya sekaligus mengidentifikasi apakah pemarkah reiterasi tersebut digunakan untuk mempertahankan kepaduan teks atau tidak

6. Guru memberikan penilaian pada hasil tulisan siswa.

\section{KESIMPULAN}

Dari hasil analisis kohesi leksikal reiterasi pada kumpulan puisi Priangan Si Jelita karya Ramadhan KH dapat disimpulkan bahwa kekuatan dan keindahan bentuk serta makna puisi tersebut tercipta melalui kepaduan unsur-unsur kohesi leksikal yang yang ada di dalamnya.

Kohesi leksikal reiterasi yang paling dominan pada kumpulan puisipuisi tersebut adalah repetisi. Penggunaan repetisi yang dominan menjadi salah satu bentuk estetis puitis, intensitas makna, dan kepaduan bahasa pada puisi-puisi di dalam Priangan Si Jelita.

Berdasarkan hasil perhitungan mengenai keberadaan kohesi leksikal reiterasi pada beberapa puisi di dalam Priangan Si Jelita, frekuensi kemunculan reiterasi terbanyak terdapat pada bagian pertama, 'Tanah Kelahiran', yaitu sebesar 45\%. Kemudian, disusul oleh bagian kedua 'Dendang Sayang', dan bagian ketiga, 'Pembakaran', dengan masing-masing sebanyak $29 \%$ dan 26\%. Ini menunjukkan bahwa puisi bagian pertama memiliki kepaduan leksikal lebih baik dibandingkan bagian kedua, dan ketiga.

Temuan ini dapat menjadi bahan masukan mengenai bagaimana tinjauan kohesi leksikal pada sebuah puisi seharusnya dilakukan. Selain itu, hasil penelitian ini dapat digunakan 
untuk menjelaskan keindahan puisi berdasarkan kekayaan pilihan kata yang memenuhi prinsip kepaduan wacana secara leksikal.

Penelitian ini memiliki implikasi pada pembelajaran bahasa Indonesia di SMP, khususnya untuk siswa kelas IX pada materi 'menyusun teks parafrase puisi sesuai dengan struktur dan kaidah teks secara tertulis'. Aspek pembelajaran ini akan membantu siswa untuk memahami penanda leksikal yang berbentuk reiterasi yang berfungsi untuk membuat suatu teks menjadi padu.

\section{Daftar Pustaka}

Aghdam, Samira Hashemi \& Yaser Hadidi. 2012. "Cohesion and Coherence in Political Newspapers and Discussion Sections of Academic Articles". International Journal on Studies in English Language and Literature (IJSELL) 3: 11-22

Alwasilah, A. Chaedar. 2006. Pokoknya Kualitatif: Dasar-dasar Merancang dan Melakukan Penelitian Kualitatif. Jakarta: PT Dunia Pustaka Jaya

De Beaugrande, Alain-Robert. 1981. Introduction to Discourse. London and New York: Longman

Depdiknas. 2008. Kamus Besar Bahasa Indonesia (KBBI). Jakarta: Gramedia

Haris, Siti NF \& Melor Md Yunus. 2014. "The Use of Lexical Cohesion among TESL Postgraduate Students in Academic Writing". Journal of Education and Human Development, 3 (2): 847-869.
Herianah. 2014. "Kohesi Gramatikal dan Leksikal Dalam Wacana Puisi Tadarusku Untukmu Karya Sus S. Hardjono". Jurnal Metalingua 12 (1): 57-69

Kridalaksana, Harimurti. 2001. Kamus Linguistik. Jakarta: Gramedia Pustaka Utama

Malgwi, Grace. 2016. "A Study of the Character of Lexical Cohesion in ESL Texts." Literacy Information and Computer Education Journal (LICEJ) 7 (1): 211-214.

Malah, Zubairu. 2015. "Lexical Cohesion in Academic Discourse: Exploring Applied Linguistics Research Articles Abstracts." Research Journal of English Language And Literature, 3 (4): 291-299

McRae, John. 1998. The Language of Poetry. London : Routledge

Pateda, Mansur. 2010. Semantik Leksikal. Jakarta: Rineka Cipta

Putra, Anggit HM. 2014. "Analisis Kohesi Gramatikal Dan Leksikal dalam Novel Kirti Njunjung Drajat Karya R. Tg. Jasawidagda". Jurnal Program Studi Pendidikan Bahasa dan Sastra Jawa, 4 (1): 45-50

Ramadhan KH. 1975. Priangan Si Jelita. Jakarta: Pustaka Jaya

Rani, Abdul, Bustanul Arifin \& Martutik. 2004.. Analisis Wacana: Sebuah Kajian Bahasa dalam Pemakaian. Malang: Bayumedia Publishing

Sudaryanto. 1993. Metode dan Aneka Teknik Analisa Bahasa. Yogyakarta: Duta Wacana University Press

Zaimar, Okke Kusuma Sumantri \& Ayu Basoeki Harahap. 2011. Telaah Wacana: Teori dan Penerapannya. Jakarta: Komodo Books 